\title{
Lecturers' Attitudes towards Online Teaching in the Learning Process
}

\author{
${ }^{*}$ Harisa Mardiana ${ }^{1}$
}

Universitas Buddhi Dharma, Tangerang, Indonesia ${ }^{1}$

E-mail: harisa.mardiana@ubd.ac.id ${ }^{1}$,soehanadiharisa@gmail.com¹

${ }^{*}$ Corresponding Author

DOI: https://doi.org/10.18326/rgt.v13i1.77-98

\section{Submission Track:}

Received: 05-04-2020

Final Revision: 23-05-2020

Available online: $01-06-2020$

\begin{abstract}
The author's interest is to investigate the lecturers' attitudes towards online teaching in the learning process which is the teaching for the $21^{\text {st }}$-century learning process and to seek the relationship among lecturers' attitudes, online teaching and learning process. The problem is many lecturers in Tangerang City area are afraid of using technology and some of them are stuttered and technology illiterate. The lecturers still prefer face to face learning in the class more campuses have provided Moodle as a platform of learning. With the circumstances of Coronavirus, the learning has moved to e-learning. In this research, the author used a mixed-method and the number of respondents was 104, data collection was obtained from questionnaires sent via Google Form and distributed through WhatsApp to the lecturers in Tangerang City area.
\end{abstract}


Data is translated into frequency and regression linear. The result showed that 73 lecturers change them toward e-learning and remain 27 lectures had difficulty in teaching online and preferred traditional learning.

Keywords: Lecturers' attitudes, online teaching, and learning process

\section{INTRODUCTION}

Technological change has made life changes, including in education. In education, the learning process can be through face-to-face or e-learning. Technology development leads to innovation so that many emerging methods are identified in e-learning. In this study, the focus is more on the increasingly popular stage of higher education and helps lecturers and students and institutions to develop further. But, many of the lecturers are afraid and technology illiterate in using e-learning ( Chiasson, Terras, \& Smart, 2015). The problem in Indonesia today is the unpreparedness of lecturers and institutions in responding to virtual learning. Many lecturers are confused using the e-learning method, they understand better if learning uses face to face which only sends and receives messages online. As happened in an online lecture at a Tangerang City university, lecturers who are afraid of technological change and technology stutterers prefer lectures using the traditional way of teaching ( De, 2018). Despite being notified, the lecturers did not heed the rules. Many lecturers do not agree to change learning from traditional or face to face to e-learning although the institutions or campuses have provided the training to use Moodle or some of the e-learning such as Google Classroom or G Suite. The previous researcher by Chin., et., al (2018) indicated that in teaching online, the lecturer strives to make the communication of the message to be conveyed in learning appropriately to students as a whole, besides that 
when giving constructive feedback, the lecturer as a supporter finds a way to promote positive messages and criticism from students. Another researcher by Belisle (2006) revealed that the benefits of teaching online make learners become independent and understand that people need to learn according to their time. In teaching online, lecturers must have cognitive and metacognitive strata so that learning is achieved ( De, 2018). Based on the researchers above, the author concluded that teaching an online course is the encouragement and support as the approach to foster positive morals in the classroom and the class opens for 24 hours and 7 days a week, and lecturers can actively build a new knowledge when interacting in the learning environment that is a strength in online learning. The purpose of the research is to investigate the lecturers' attitudes toward online learning and to seek online teaching in the learning process.

\section{Lecturers' Attitudes}

The important key for lecturers in teaching is to have adequate knowledge. This must be addressed by the ability and skills of lecturers in preparing their teaching. And it is reflected in lecturers' attitudes who have a conceptual teaching framework, especially with online teaching ( Bakia, Shear, Toyama, \& Lasseter, 2012). Unfortunately, not all lecturers have complete knowledge about the tools available, especially in online teaching ( Arkorful \& Abaidoo, 2014). Lecturers' attitudes in teaching online can be shown from their knowledge, especially in teaching online. Their knowledge in online teaching is a belief that can transform traditional teaching knowledge into 
online where the lecturers' attitudes are shown on "the true belief' and defines knowledge as a dynamics human process that justifies personal belief in the truth ( Dalkir, 2005). The lecturers believe that to produce innovation, it is necessary to create and learn visual knowledge so that the knowledge becomes new knowledge and spreads and is realized in learning products (p.58).

The lecturers do not depend on a textbook when teaching online. Also, the adaptation of information communication technology will increase access to resources. Technologies such as e-mail and the Internet tend to push lecturers toward fundamentally different teaching (Mählck \& Chapman, 2004). Lecturers must have specific knowledge about technology and combine it with existing pedagogical content knowledge (Hutchison \& Reinking, 2011). Another problem is, many lecturers neglect their ability to teach online, they prefer teaching in front of the class through textbooks ( (Kebritchi, Lipschutz, \& Santiague, 2017)). Other research Davis, F. D (1989) identified a close relationship between having technology use skills and the level of technology integration in the classroom. The lack of computers on campus and access to the Internet and infrastructure delays and training costs and poor ICT competence are significant obstacles. According to Bray (2007) stated that behavior in using e-learning systems has an inverse relationship between computer experience and the use of e-learning. Many lecturers consider the elearning program to not meet the needs of them or students due to the lack of integration of technology into teaching. However, the factors that influence the successful use of technology and e-learning in learning are the attitudes and beliefs of lecturers towards technology (Alazam , Bakar, Hamzah, a, \& Asmiran, 2013). Because e-learning in a university or institutional environment has found pedagogic variations similar to face-to-face learning, this shows that not all lecturers conduct online teaching on the same pedagogic 
basis, or the same technological and have a strict discipline and high technological knowledge ( Bakia, Shear, Toyama, \& Lasseter, 2012).

\section{Online Teaching}

Infrastructure plays an important role in online teaching, and if infrastructure and training are provided, online teaching will run smoothly (Mardiana H. , 2018). In learning how to synchronize and asynchronous can be shown by instructors who can motivate students. According to Partlow \& Gibbs (2003) found that online teaching was designed from constructivist principles that were relevant, interactive, project-based and collaborative and controlled students in learning. Besides Keeton, M.T. (2004) stated that effective online teaching practices are based on a face-to-face practice framework and this requires teaching strategies that develop the creation of a supportive environment for the activeness of students. It can rely on synchronous. But Internet technology infrastructure in campus has to increase bandwidth so that learning becomes synchronous. According to Perveen (2016) synchronous e-learning involves active discussion, direct feedback and there is familiarity in learning interactions. Hence, the involvement in the classroom carries over to e-learning. Learning is more dynamic than through media with time lags. The discussions were livelier and the questions were answered immediately right away. The speed and closeness of synchronous online learning generates the same level of accountability and involvement as classroom attendance, so ideas that emerge can compete and complement each other in real time and tight schedule dan good infrastructure of technology 
Internet. Whist a synchronous e-learning is facilitated by media such as e-mail and discussion boards that connect work between students and lecturers, and this discussion board can be used on students who cannot be online at the same time. And asynchronous is the key to flexible e-learning. Many students take online learning because this asynchronous is combined with education, family, work and other commitments. According to ( Perveen, 2016) asynchronous elearning allows students to enter learning whenever they download documents or send messages to lecturers or classmates. Students have a lot of time to improve their contribution in learning compared to synchronous e-learning. To reduce student confusion, it is necessary to prepare an explicit online portal and instructional content. Do not hesitate to direct students to the teaching material and to redo learning. In this way, other students can benefit from reading questions and answers. It may also be that other people can contribute with additional questions or answers and suggestions and solutions. However, activating collaboration and connection in learning is justified ( De, 2018).

\section{RESEARCH METHOD}

This study uses a quantitative method mixed with a semi-structured qualitative method, by investigating the relationship between variables (Cresswell, 2014). The number of respondents was 104 and data collection was obtained from the questionnaires sent via Google Form and distributed through WhatsApp. A semi-structured qualitative method as the interview with 15 lecturers for 2-3 hours in December 2019 -February 2020. Data for the independent (predictor) variables were from questionnaires which the author used the 2 questions which dimension of lecturers' attitudes towards the technological change and the lecturers towards online teaching. 


\section{Hypothesis}

There are three hypothesis on this research. They are: First, There is a statistically significant relationship between the frequency-independent variable of lecturers' attitudes and the learning process, Second, There is a statistically significant relationship between a frequency-independent variable of online teaching and the learning process and Third, There is the independent variable frequency of lecturers' attitudes towards online teaching in participating best in predicting the dependent variable on the learning process.

\section{Data Analysis}

The research used five questions of each dimension were analyzed using frequency for finding the most using the dimensions and regression linear test for independence in the testing of statistical significance of the relationship between lecturers' attitudes towards online teaching and the learning process. Fist to find the reliability and the correlation of data to obtain the next step of the procedure.

To analyze the data, first, the study needs to find the reliability of data and correlation between them. Table 1 is shown the reliability and correlation between the lecturers' attitudes, online teaching, and the learning process.

Table 1. Descriptive Statistics Reliability and Correlations of Lecturers' Attitudes and Online Teaching in the Learning Process

$\begin{array}{llll}\text { No Variables } & \text { Reliability } & \text { Correlation }\end{array}$




\begin{tabular}{|c|l|c|c|c|c|}
\hline & & $\begin{array}{l}\text { Lecturers' } \\
\text { Attitudes }\end{array}$ & $\begin{array}{l}\text { Online } \\
\text { Teaching }\end{array}$ & $\begin{array}{l}\text { Learning } \\
\text { Process }\end{array}$ \\
\hline 1 & $\begin{array}{l}\text { Lecturers' } \\
\text { Attitudes }\end{array}$ & 0.700 & 1 & 0.650 & 0.897 \\
\hline 2 & $\begin{array}{l}\text { Online } \\
\text { Teaching }\end{array}$ & 0.749 & 0.650 & 1 & 0.919 \\
\hline 3 & $\begin{array}{l}\text { Learning } \\
\text { Process }\end{array}$ & 0.897 & 0.897 & 0.919 & 1 \\
\hline
\end{tabular}

From the data above, the reliability of questionnaires is shown that lecturers' attitudes are 0.700. It showed that the reliability is strong, the reliability of questionnaires of online teaching showed of 0.749 and it is strong. When the lecturers' attitudes and online teaching is in the learning process, the reliability of questionnaires is shown 0.919 , which means that significantly strong. For the correlation between lecturers' attitudes and online teaching are shown moderate, it is 0.650 , but for the lecturers' attitudes to the learning process showed 0.897 means quite strong. From data questionnaires of reliability and correlation are shown that the data is valid.

\section{FINDING AND RESULT}

Now, the research calculated frequency for each of the items in the dimension of data. The first research is finding the frequency of lecturers' attitudes in the learning process.

Table 2. Descriptive Statistics of the frequency of Lecturers' Attitudes, Online Teaching in the learning process 

Variables
Means
SD
Freq.
$(\%)$

Frequency of Lecturers in the learning process

$\begin{array}{lllll}\text { Digital Literacy } & 3.63 & 0.558 & 70 & 67.3 \\ \text { Lecturers' Collaboration } & 3.60 & 0.616 & 68 & 65.8 \\ \text { Lecturers' on-time } & 3.58 & 0.618 & 65 & 62.5 \\ \text { Lecturers' beliefs } & 3.51 & 0.623 & 60 & 57.7 \\ \text { Lecturers' Spirits } & 3.38 & 0.728 & 54 & 51.9\end{array}$

Online Teaching in the learning process

$\begin{array}{lllll}\text { Interactive in teaching } & 3.67 & 0.530 & 73 & 70.2 \\ \text { Online Knowledge Base } & 3.63 & 0.525 & 67 & 64.4 \\ \text { Ask and Comments } & 3.50 & 0.639 & 58 & 55.8 \\ \text { Lecturers' preparedness } & 3.45 & 0.681 & 57 & 54.8 \\ \text { Lecturers' Training } & 3.39 & 0.716 & 54 & 51.9\end{array}$

Lecturers Online Learning Process

$\begin{array}{lllll}\text { Lecturers' attitudes } & 16.70 & 1.576 & 70 & 67.31 \\ \text { Online Teaching } & 16.64 & 1.672 & 73 & 70.19\end{array}$

Source: Data process

From the data of frequency of lecturers' attitudes in the learning process is shown that digital literacy is the highest frequency (70 participants or 67.3\%) and frequency from online teaching in the learning process is the highest (73 participants or $70.2 \%$ ). In the interview was done, most lecturers have felt 
happy when the interaction between lecturers and students, also the interaction can be lecturing and describing the material. Most of the lecturers explain the material by sending the voice message. The students may color the material which is important for them. Alamsyah, A. (2018) stated that the learning process is a relatively permanent change from behavioral learning because the practice is strengthened and the learning process is carried out in differences in students' experiences and thoughts which will lead to different attitudes. Also, the NSW report (2017) indicated that lecturers who have digital literacy abilities and skills can design material online. The design of the material can involve students to ask questions and make comments. Moreover, in answering the material taught will lead to high interaction and learning can run smoothly.

The second highest frequency of lecturers' attitudes in the learning process is lecturers' collaboration (68 participants or 65.8\%). The second highest frequency of online teaching is an online knowledgebase (67 participants or $64.4 \%$ ). The lecturers can collaborate with other lecturers although they have a different subject of teaching, and this will make the students have a broad knowledge. In successful collaboration with the others, the lecturers must conduct the learning process, and the lecturers must have the same level of knowledge, ability, and skills (Caskey \& Carpenter, 2014). Online knowledge is providing information, services and sharing online. However, in analyzing the existing problems in learning, lecturers must understand correctly because it requires a great effort in the learning process so that the learning products provided must refer to a pedagogical approach that can build the learning process can be reused if needed (Hajric , 2018); ( Dalkir, 2005).

The third highest frequency of lecturers' attitudes in the learning process is the lecturers' punctual or on-time teaching (65 participants or 
$62.5 \%)$. The third highest frequency of online teaching is to ask and comment (58 participants or 55.8\%). To be effective in teaching, lecturers must start with time management and set priorities, organize the day around the most important tasks (Darby, 2017). Setting priorities can help keep the noise on track throughout the day, even if something unexpected happens and becomes a workload. In the interview was taken, lecturers who are on time will become qualified lecturers. Being able to manage teaching time, lecturers can also set learning priorities. Crisis related to lecturer behavior will have an impact on student learning outcomes and will lead to new crises ( Bakia, Shear, Toyama, $\&$ Lasseter, 2012). When there are potential questions from students, it must be utilized. According to Graesser and Person (1994), students ask several questions in search of knowledge. If students only ask a few questions, then the lecturer must ask whether students understand learning. Usually, students do not ask for attention but the encouragement of lecturers to make students ask is quality thinking or cognitive questions (White \& Gunstone, 1992); ( Chin $\&$ Osborne, 2018) with questions that are factual, procedural or outside of human thought.

The fourth highest frequency of lecturers' attitudes in the learning process is lecturers' beliefs (60 participants or 57.7\%). And the fourth highest frequency of online teaching in the learning process is lecturers preparedness (57 participants or 54.7\%). Belief focuses on instruction in presenting teaching, and as a form of belief that aims to teach and can form students in a belief system that consists of great confidence based on evidence and reason (Richardson , 1996). The lecturer helps students to change their beliefs who feel they do not understand into understanding. Moreover, the learning process 
can help students by identifying the value of their beliefs related to teaching ( Mardiana \& Daniels, 2019). Moreover, the lecturers' must-have preparedness in online knowledge and skills in using technology. For online learning, institutions must build on the preparedness of the online learning infrastructure. There is a big significant difference for lecturers who have the readiness to teach. The reflection of lecturers who have continuous preparedness in teaching and has great control and a good learning climate and can achieve the full learning objectives ( Paolini, 2015). It can further be shown that teachers who are well qualified and have high-quality teaching can close the achievement gap between economically disadvantaged students and those who are rich (Kneale, 2009).

The fifth frequency of lecturers' attitudes in the learning process is lecturers' spirits (54 participants or 51.9\%) and the fifth frequency of lecturers' training is (54 participants or 51.9\%). When we had the interview with the lecturers about their spirit to teach the students, the lecturers stated that the enthusiasm of spirit in teaching is to help students who do not understand anything to become understand, from those who cannot do math problems to know how to do mathematics. Making students independent is the pride of lecturers, students can be independent because of the guidance of lecturers which is to have a proud feeling. So that lecturers will continue to teach until old age because of these circumstances. According to Slavin, R.E. (1991) the spirit of learning is the tendency of a high heart to learn that obtain the information, knowledge, skills through the effort of teaching or experience and Hardjana (1994) stated that the spirit of learning and teaching is the spirit to provide time, energy, effort to absorb and organize information, knowledge, and skills that we receive and obtain through various means. Moreover, the role of the lecturer is one of the factors that influence student learning 
achievement so that the lecturer is a component that has a strategic role in learning and has the key to improving the quality, relevance, and efficiency of education (Tosepu, 2019). Enable to optimally prepare their competencies, lecturers must have the ability, expertise, and skills in teaching both online and in front of the class. Hence, it can be ascertained that the better the competence of lecturers, the student learning achievement will increase (Preston, 2012). Having adequate behavior and abilities to develop students is the task of the lecturer and is part of the competency (Alamsyah, 2018). Great lecturers become important for student achievement, and hence, the lecturers can develop sustainable professionals in their careers (Kelly, 2019). As the interview to the lecturers was taken, the lecturers mentioned that an ideal training is needed every semester because to face new challenges in education, especially related to technology development, lecturers must update their professionalism to be more adequate. Lecturers must understand digital education solutions, including online teaching methodologies and how to give online exams which sometimes give problems to students with an Internet connection (Yucel, 2007). In the interview, one of the lecturers has indicated that it is important to remember that not all lecturers immediately feel comfortable using technology and hardware and software in an educational platform. Training to achieve educational excellence must have a training program that covers how technology plays a role in learning and learning content management systems.

The last frequency is lecturers on the online learning process (70 participants or $67.31 \%$ ). When the interview was done, most of the lecturers would move from traditional teaching to online teaching to bring them to 
continue teaching. According to Redmond (2011) changes in teaching with technology put lecturers under pressure so that they can embed technological knowledge into online teaching so that lecturers are capable and skilled in teaching online. Another researcher Chiasson., et., al (2015) mentioned that with the change in teaching using technology, many lecturers have been pressured because of instilling technology knowledge into online teaching so that they are capable and skilled in teaching online. Therefore, teaching simulations can challenge students to involve them in online-based activities that require the development of lecturer and student skills. As a result, teaching tools on the Internet will empower them to learn while doing something so that their abilities and skills can be sharpened ( Mardiana \& Daniels, 2019). It is shown that from 104 lecturers, 70 lecturers wish to change towards e-learning and 34 lecturers have difficulties using e-learning and preferred traditional learning. The lecturers wish to continue teaching for their careers and they have trained e-learning, had taken online learning courses to make them suitable in the job. In online teaching, it is shown that 73 lecturers have moved to online teaching, and 31 lecturers are still trying to learn about technology which enables them to have the ability and skill in teaching online. Almost all lecturers who have difficulty in online teaching do not move quickly to adopt the technology. Bray (2007) and Davis (1998) revealed that generally lecturers who find it difficult to use technology in teaching are lecturers who are technology illiterate, are not skilled in ICT and make them difficult to change. Most of them are lecturers who do not have a belief in using technology. Next, the research showed the relationship between lecturers' attitudes toward online teaching and it is shown in table 3. 
Table 3. Descriptive Statistics of the Relationship between Lecturers' Attitudes toward Online Teaching in Learning Process

\begin{tabular}{|c|c|c|c|c|}
\hline Variables & $\mathbf{R}$ & $\begin{array}{l}\text { R } \\
\text { Squared }\end{array}$ & F Change & $\begin{array}{l}\text { Sig. } \\
\text { Change }\end{array}$ \\
\hline Lect. Att -learn.process & 0.818 & 0.766 & 502.756 & 0.000 \\
\hline $\begin{array}{l}\text { Online teaching- } \\
\text { learn.process }\end{array}$ & 0.919 & 0.845 & 557.349 & 0.000 \\
\hline $\begin{array}{l}\text { Lect. Attd.-Online-Learn } \\
\text { process }\end{array}$ & 0.897 & 0.802 & 418.901 & 0.000 \\
\hline
\end{tabular}

Source: Data process

From table 3 the descriptive statistics for the relationship lecturers' attitudes towards online teaching in the learning process is shown that $\mathrm{R}$ is 0.818 indicated as predicted to predict the learning process, and $\mathrm{R}$ Squared measures the proportion of the variable of lecturers' attitudes and learning process which is shown 0.766. It means that the proposition of lecturers' attitudes in the learning process is $76.7 \%$ and remain $23.4 \%$ is from others that it does not include in this research. For F-Change showed 502.756>0.05 (James, G., et., al 2013). It can be the answer to the research hypothesis number 1. So, it concluded that in lecturers' attitudes and learning process that Ho is rejected and $\mathrm{Ha}$ is accepted.

The relationship between online teaching and learning process is 0.919 and $\mathrm{R}$ Squared is 0.845 . It is indicated that the relationship between online teaching and learning process is $84.5 \%$ and remain $15.5 \%$ is from other which does not include in this research. For F-Change showed 557.349>0.05. So the 
hypothesis number 2 is answered and the conclusion is there is a relationship between online teaching and learning process. And Ho is rejected and $\mathrm{Ha}$ is accepted.

The relationship among lecturers' attitudes, online teaching and learning process are shown $\mathrm{R}$ is 0.897 and $\mathrm{R}$ Squared is 0.802 . It is indicated that the relationship among lecturers' attitudes, online learning and learning process is $80.2 \%$ and remain 19.8 is from others which do not include in this research. For F-Change showed 218.901>0.05. So the hypothesis number 3 is answered and it can conclude that in lecturers' attitudes, online teaching and learning process, Ho is rejected and Ha is accepted.

\section{RESULTS \& DISCUSSION}

Lecturers' attitudes have an important role in the online teaching and learning process. Lecturers' attitudes are the important components in the learning revolution which triggers the attitudes of lecturers to be more active in teaching ( Mardiana \& Daniels, 2019). The most important thing is education focuses on students who maximize teaching resources and time. From the frequency of the lecturer's online learning process, 70 lecturers from lecturers' attitudes and 73 lecturers from online teaching are eager to improve their attitudes and abilities and skills. This showed that 70 of 104 lecturers eager to change. These changes can be viewed from how much the changes and is shown from beliefs, as strong desires and changes in the knowledge and abilities and skills gained in the experience, training and teaching readiness of the lecturer (Kneale, 2009). While 30 lecturers from lecturers' attitudes and 27 lecturers from online teaching are having difficulty to change the face to face teaching into online teaching. When the interview was taken, the main factor 
is because of they afraid of technology and technologically illiterate, so that it takes them a long time to learn to change. Besides, they also do not have a strong belief to change even though the change has been done by training and increasing knowledge (Hajric , 2018); ( Dalkir, 2005).

In online learning, lecturers enter the realm of constant learning which embraces the application of theory in the real world through multimedia, video, and interactivity. Hence, lecturers can effectively utilize the power of technology in online learning (Hajric , 2018). In the interview was done most lecturers stated that the problem is the campus infrastructure that must accommodate access to learning so that the benefits that have been used by lecturers in teaching can be the progress of the campus and students. Therefore the benefits of infrastructure must be accompanied by the ability of lecturers to teach and understand digital literacy and use it into online curriculum construction (Caskey \& Carpenter, 2014). In certain contexts and small class sizes, synchronization can be done well and supported by adequate Internet technology. The positive effect is immediately felt by students and lecturers after completing learning because by using a synchronous learning approach like this can take place well.

Besides, online learning is increasingly in demand by all lecturers because of the flexibility of the schedule and the cost-effectiveness of education and learning opportunities located elsewhere through distance teaching so that lecturers and students can access the learning ( De, 2018). Besides, lecturer training in online teaching must be implemented so that lecturers are more constant in teaching. Online teaching resources as a means of updating and sharpening lecturers that force lecturers to continue to improve 
their teaching through professional development in the daily life of lecturers ( Dalkir, 2005). The advantage of using asynchronous is that e-learning is flexible, pacing and affordability Lecturers who choose asynchronous because of the many commitments that must be carried out and their families and other needs, besides that students also have work that cannot be left out, so that using the asynchronous approach to learning can be carried out, besides using the asynchronous approach it provides lower costs even though to interact not in real time but still can ask the lecturer via email or social media. The acceleration of learning depends on the learner who offers the opportunity to work at the same time learning with minimal costs.

\section{CONCLUSION}

Now Education is entering a new era - the era of online education. But there is no other reason that can be avoided from teaching online. Online education is an education that makes sense and is a useful learning method for sharpening technology skills that require new skills. Lecturers who teach in tertiary institutions can do their learning wherever they are, for example in distant places that are not relevant for teaching, but the lecturers can teach.

However, lecturers need to plan to actively integrate online classes as often as possible. In learning, it takes a time limit and calendar that determines attendance directly. Posting announcements provide further explanation and provide tips on upcoming assignments and reply to online discussion posts that are important in answering student questions. So, when teaching directly lecturers need not expect students to continue without regular guidance, because the involvement of faculty and campus will apply on the Internet. 
In the future, if lecturers have mastered online teaching and they will change, online learning will be fun and students can do quality learning just like face to face learning. With a focus on online teaching knowledge, lecturers are forced to know and deepen the technology that is the 21st-century teaching reference. The ability and skills and expertise of lecturers to automate teachings, such as methods, teaching materials and assessment digitally can track student progress with reporting tools and analytic platforms created by the campus. Moreover, student progress can be demonstrated in real-time. Students are not only able to empower digital technology but can also go beyond functional and relevant exploration of learning.

\section{REFERENCES}

Arkorful, V., \& Abaidoo, N. (2014, December). The role of e-learning, the advantages and disadvantages of its adoption in Higher Education. International Journal of Education and Research , 2(12), 397-410. Retrieved from https://www.ijern.com/journal/2014/December2014/34.pdf

Bakia, M., Shear, L., Toyama, Y., \& Lasseter, A. (2012). Understanding the Implications of Online Learning for Educational Productivity. US Department of Education, Office of Educational Technology. Washington, DC: Center for Technology in Learning SRI International. Retrieved from https://tech.ed.gov/files/2013/10/implications-onlinelearning.pdf

Bray, D. A. (2007). Being a Systems Innovator. In R. T. Watson, Information Systems (pp. 4-15). Idaho, Idaho State, USA: Global Text Project. Retrieved from http://www.uky.edu/ gmswan3/777/IS_Book.pdf 
Chiasson, K., Terras, K., \& Smart, K. (2015). Faculty Perceptions Of Moving A Face-To-Face Course To Online Instruction. Journal of College Teaching \& Learning - Third Quarter , 231-240. Retrieved from https://files.eric.ed.gov/fulltext/EJ1067275.pdf

Chin , C., \& Osborne, J. (2018, March). Students' questions: a potential resource for teaching and learning science. Studies in Science Education, 4(1), 1-39. doi:10.1080/03057260701828101

Dalkir, K. (2005). Knowledge Management in Theory and Practice. Burlington, MA 01803, USA: Elsevier Butterworth-Heinemann.

De, B. (2018, February 4). Traditional Learning Vs. Online Learning. Retrieved from Learning Industry: https://elearningindustry.com/traditional-learning-vs-online-learning

Hrastinski, S. (2008, November 18). Asynchronous and Synchronous ELearning. Retrieved from EDUCAUSE REVIEW: https://er.educause.edu/articles/2008/11/asynchronous-andsynchronous-elearning

Mardiana, H., \& Daniels, H. K. (2019, October). Technological Determinism, New Literacies and Learning Process And The Impact Towards Future Learning. Journal of Educational Science and Technology, 5(3), 219229. doi:10.26858/est.v5i3.8662

Mardiana, H., \& Daniels, H. K. (2019, March). The Role of Rationality and Technological Change in Learning Process. Indonesia Journal of Learning Education and Counseling, 1(2), 151-158. doi:10.31960/ijolec.vli2.64

Paolini, A. (2015). Enhancing Teaching Effectiveness and Student Learning Outcomes. The Journal of Effective Teaching - an online journal devoted to teaching excellence, 15(1), 20-33. Retrieved from https://files.eric.ed.gov/fulltext/EJ1060429.pdf 
Perveen, A. (2016). Synchronous and Asynchronous E-Language Learning A Case Study of Virtual University of Pakistan. Open Praxis, 8(1), 2139. doi: http://dx.doi.org/10.5944/openpraxis.8.1.212

Alazam , A. O., Bakar, A., Hamzah, R., a, \& Asmiran, S. (2013). Lecturers' ICT Skills and ICT Integration in the Classroom: the case of Vocational and Technical Lecturers in Malaysia. Creative Education, 3(8), 70-76.

Caskey, M. M., \& Carpenter, J. (2014, October). Building Teacher Collaboration School-wide. (A. Magazine, Producer) Retrieved from Association for Middle Level Education (AMLE): https://www.amle.org/BrowsebyTopic/WhatsNew/WNDet/TabId/270/ ArtMID/888/ArticleID/446/Building-Teacher-Collaboration-Schoolwide.aspx

Cresswell, J. W. (2014). Research Design: Qualitative, Quantitative and Mixed Method Approaches (4th Edition ed.). (V. Knight, Ed.) Thousand Oak, California, USA: SAGE Publication, Inc. Retrieved January $\quad 31, \quad 2020, \quad$ from http://fe.unj.ac.id/wpcontent/uploads/2019/08/Research-Design_Qualitative-Quantitativeand-Mixed-Methods-Approaches.pdf

Darby, F. (2017). How to Be a Better Online Teacher - Advice Guide. (J. M. Lang, Editor, \& D. S. Chronicle, Producer) Retrieved from The Chronicle of Higher Education: https://www.chronicle.com/interactives/advice-online-teaching

Hajric , E. (2018). Knowledge Management System and Practices - A Theoretical and Practical Guide for Knowledge Management in Your Organization . Jacksonville, Florida, USA: Helpjuice.

Hutchison, A., \& Reinking, D. (2011). Teachres' Perception of Integrating Information and Communication Technologies into Literacy 
Instruction: A National Survey in the United States. Reading Research Quarterly, 312-333.

Kebritchi, M., Lipschutz, A., \& Santiague, L. (2017). Issues and Challenges for Teaching Successful Online Courses in Higher Education: A Literature Review. Journal of Educational Technology Systems, Vol. 46(1), 4-29. doi:10.1177/0047239516661713

Kelly, M. (2019, June 23). Importance of Effective Teacher Training. Retrieved from ThoughCo. Importance of Effective Teacher Training: https://www.thoughtco.com/importance-of-effective-teacher-training8306

Kneale, P. (2009). Teaching and Learning for Employability. In H. Fry, S. Ketteridge, \& S. Marshall, A Handbook for Teaching and Learning in Higher Education (pp. 99-112). NW: Routledge.

Mählck, L. O., \& Chapman, D. W. (2004). Chapter 14: Effective Use of Technology to Improve Education: Lesson for Planners. In L. O. Mählck, \& D. W. Chapman, Adapting Technology for School Improvement: A Global Perspective (p. 298). Paris: International for Education Planning.

Mardiana , H. (2018, March). Lecturer's Attitude towards Advance Technology and Its Impact to the Learning Process: Case study in Tangerang City Campuses . Journal of Educational Science and Technology , 4(1), 12-25 . doi:http://dx.doi.org/10.26858/est.v4i1.4974

Preston, J. P. (2012). Fostering the Learner Spirituality of Students: A Teaching Narrative. Brock Education, 21(2), 22-35. Retrieved from https://pdfs.semanticscholar.org/2806/67a2cd586cf5c41f1b4bae719b7 37cc61220.pdf

Richardson, V. (1996). The Role of Attitudes and Beliefs in Learning to Teach. In J. Sikula , \& J. Sikula (Ed.), Handbook of research on teacher education (2 ed., pp. 102-119). New York, NY, USA: MacMillan. 
Tosepu, Y. A. (2019, March 19). Pendidikan Untuk Kehidupan. Retrieved from Education is Simple the Soul of a Society as it passes from one generation to another: https://yusrintosepuabdikarya.wordpress.com/2019/03/19/perandosen-dalam-meningkatkan-motivasi-dan-prestasi-belajar-mahasiswa/

White, R. T., \& Gunstone, R. F. (1992). Probing Understanding . London: Falmers Press.

Yucel, A. S. (2007, January). Factors Affecting Teaching The Concept Of Renewable Energy In Technology Assisted Environments And Designing Processes In The Distance Education Model . Turkish Online Journal of Distance Education-TOJDE, 8(1), 114-124. Retrieved from https://www.researchgate.net/publication/26449602_Factors_affecting _teaching_the_concept_of_renewable_energy_in_technology_assisted _environments_and_designing_processes_in_the_distance_education _model 